\title{
Progress and Gaps in Research on Urban Green Space Morphology: A Review
}

\author{
Hao Zou $@$ and Xiaojun Wang * \\ Department of Landscape Architecture, School of Architecture, Southeast University, Nanjing 210096, China; \\ haozou@seu.edu.cn \\ * Correspondence: wangxj@seu.edu.cn
}

check for updates

Citation: Zou, H.; Wang, X. Progress and Gaps in Research on Urban Green Space Morphology: A Review. Sustainability 2021, 13, 1202.

https://doi.org/10.3390/su13031202

Academic Editor: Zhaowu Yu

Received: 25 December 2020

Accepted: 21 January 2021

Published: 24 January 2021

Publisher's Note: MDPI stays neutral with regard to jurisdictional claims in published maps and institutional affiliations.

Copyright: (c) 2021 by the authors. Licensee MDPI, Basel, Switzerland. This article is an open access article distributed under the terms and conditions of the Creative Commons Attribution (CC BY) license (https:// creativecommons.org/licenses/by/ $4.0 /)$.

\begin{abstract}
Examining urban green space from the perspective of morphology is an important way to perform the current practice of urban green space planning, preserve and restore the function of urban natural habitats, and maintain good spatial patterns of urban ecological environment. Based on the investigation and analysis of relevant scientific literature on urban green space morphology, we discussed the regional and temporal context and the knowledge frame of the relevant research on urban green space morphology. The frontier methods and technologies within the research category were summarized, including studies on urban green space planning, studies on urban green space pattern and urban landscape pattern, and studies on strategies, planning management, and solutions for sustainable development of urban green space. Finally, the existing problems in urban green space morphology research were discussed, and the future research directions and objectives were proposed.
\end{abstract}

Keywords: urban green space; morphology; knowledge frame; research frontiers

\section{Introduction}

Urban green space contains or supports the corresponding natural environment system. It is the only space entity with natural biological activity and regenerative mechanism in the urban ecosystem, which plays a significant role in alleviating the negative effects of the urban artificial environment with its ecological service function.

There is no strict and accepted definition of urban green space, and the term seems to be used loosely by different researchers. In order to address the confusion that may occur, the authors in this paper follow the definition suggested by Swanwick et al. Green space is land that consists predominantly of unsealed, permeable, soft surfaces such as soil, grass, shrubs and trees. Urban green space is therefore an umbrella term for all areas of land covered by this definition of green space, whether publicly or privately owned [1].

Since the 21st century, the construction of urban green space has made tremendous progress in China. In the past 30 years, the average rate of urban green space has increased from $18.9 \%$ to $30 \%$, and the overall urban ecological environment has been substantially improved. The preservation and restoration of the ecological and environmental functions of urban green space have become one of the essential contents of urban sustainable development. The shifting of society's attention from quantity to quality calls for the urgency in studying and understanding urban green space as a whole. Therefore, the study of urban green space morphology at a city scale has both theoretical and practical significance for an in-depth understanding of the overall ecological and environmental functions and effects of urban natural elements and space, as well as its application in urban planning and construction. 
Based on the Web of Science Core Collection, this paper analyzed the global scientific literature published over the past 25 years from the perspective of urban green space morphology. This paper intends to explore the following issues: (1) the spatiotemporal distribution and knowledge frame of urban green space morphology studies; (2) the research category of urban green space morphology and its cutting-edge methods and technologies; (3) the existing problems and perspectives of urban green space morphology research.

\section{Methods}

We used the core collection database of Web of Science and created search strings combining the terms ("urban green space" OR "urban greenspace" OR "urban greenness") with (distribution OR form OR pattern OR morphology). In the selection of the theme word "urban green space", "urban open space" is ruled out since it refers to all open spaces outside of buildings, thus bringing broadness and uncertainties. The concept of "morphology" is deeply rooted in Western classical philosophy and the empirical philosophies derived from it. "Morphology" includes two important approaches. One is the analytical process taken from parts to the whole, which studies the abstract correlation of any local form that constitutes a composite whole or a Gestalt. The other is to emphasize the transformation of objective matters and to understand the sequential relationship of matters with respective to time. Therefore, the "morphology" of urban green space can be understood from the basic levels of "form", "distribution", and "pattern" and their correlations.

From the 657 articles found based on the above search strings, this paper used CiteSpace software to filter the research results and selected the most important ones in the field of urban green space morphology. As a citation visualization analysis software, CiteSpace is mainly used to reflect the research frontiers of citing articles, the knowledge basis of cited literature, and the research frontier fields represented by clustering results based on its advanced co-citation analysis function.

Based on the interpretation of the technical parameters, and practical instructions combined with the underlying design principles showed in the CiteSpace Manual [2,3], specifically, 657 articles retrieved were analyzed for co-citation with author's keywords as the term source. Using 2 years as a period slice, the top 50 most cited articles within each period were network clustered. The cluster labels were extracted based on the log likelihood ratio (LLR) algorithm. The results showed that the modularity $\mathrm{Q}$ was 0.7322 (above 0.3), indicating that the network clustering structure was significant. The mean silhouette value was 0.3131 (below 0.5), suggesting a slightly lower level of general network homogeneity. However, according to the cluster details, the silhouette that represented the internal homogeneity in all the clusters was above 0.600 , which combined with the cluster size, indicating that the silhouette of each cluster was of high confidence (Table 1).

In terms of cluster labels, the higher their LLR is, the more representative they are in their respective clusters. Table 1 listed the potential top 5 labels in various clusters. The LLR of the first label in each cluster is not highly significant, suggesting that there is some degree of relevance between potential labels in certain clusters. Based on this finding, we conducted manual selection and proposed the relevant subject categories that the study of urban green space morphology focuses on. The 304 potential articles (see Supplementary Materials) can be categorized into 10 types and are titled "A to J" (Table 2). 
Table 1. Results of co-citation analysis of searched literature based on CiteSpace.

\begin{tabular}{|c|c|c|c|}
\hline Clusters & Size & Silhouette & $\begin{array}{l}\text { Extracted Cluster Labels from Keywords Based on } \\
\text { LLR Algorithm }\left(1.0 \times 10^{-4}\right)\end{array}$ \\
\hline 0 & 20 & 0.889 & $\begin{array}{l}\text { spatial-temporal gradient analysis (169.28); Xiamen } \\
\text { island (161.75); using landscape metrics (152.92); } \\
\text { network model (148.60); urban environmental element } \\
\text { (136.46); residential housing price (136.46) }\end{array}$ \\
\hline 1 & 20 & 0.69 & $\begin{array}{c}\text { compact city (201.21); Hong Kong (192.12); differential } \\
\text { community effect (134.86); compact cities (118.45); } \\
\text { sustainable urban greening strategies (118.45); urban } \\
\text { green space (118.37) }\end{array}$ \\
\hline 2 & 36 & 0.62 & $\begin{array}{l}\text { urban green space (409.43); urban greenspace (397.97); } \\
\text { urban agriculture (387.92); Chinese cities (276.55); } \\
\text { comparative study (276.55) }\end{array}$ \\
\hline 3 & 34 & 0.923 & $\begin{array}{c}\text { spatial pattern (311.98); land surface temperature } \\
\text { (301.77); urbanized Beijing metropolitan area (166.1); } \\
\text { urban heat island pattern (158.66); anisotropic cooling } \\
\text { distance (150.02) }\end{array}$ \\
\hline 4 & 20 & 0.744 & $\begin{array}{l}\text { biodiversity conservation (102.32); urban environment } \\
\text { (102.32); street tree (94.36); aerial photograph (68.76); } \\
\text { high spatial resolution (68.76); urban residential } \\
\text { landscape (68.76); mapping land cover (68.76) }\end{array}$ \\
\hline 5 & 32 & 0.755 & $\begin{array}{l}\text { socio-economic inequalities (140.58); private land } \\
\text { (140.58); carbon storage (133.14); urban tree stock } \\
\text { (124.50); socio-ecological exploration (108.35) }\end{array}$ \\
\hline
\end{tabular}

Table 2. Subject categories of potential literature.

\begin{tabular}{|c|c|c|}
\hline Clusters & Subject Categories & Sum of Studies \\
\hline 2 & $\begin{array}{c}\text { (A) The Study of Urban Green Space Planning: urban greenway, } \\
\text { urban green belt, urban green wedge, urban green space system } \\
\text { and urban green/ecological network }\end{array}$ & 18 \\
\hline 0 & $\begin{array}{c}\text { (B) The Study of Urban Green Space Pattern and Urban } \\
\text { Landscape Pattern }\end{array}$ & 32 \\
\hline 1 & $\begin{array}{c}\text { (C) The Study of Sustainable Development of Urban Green Space: } \\
\text { strategies, planning management and solutions for sustainable } \\
\text { development of urban green space }\end{array}$ & 26 \\
\hline 2 & $\begin{array}{l}\text { (D) The Study of Urban Green Infrastructure: urban green } \\
\text { infrastructure, urban forest and urban agriculture }\end{array}$ & 14 \\
\hline 5 & $\begin{array}{l}\text { (E) The Study of Urban Ecosystem Service: the theories and } \\
\text { strategies of urban ecosystem service, and its supporting service } \\
\text { and regulating service (including pollination, air purification, } \\
\text { climate regulation, runoff regulation, storm resistance and } \\
\text { noise regulation) }\end{array}$ & 30 \\
\hline 5 & $\begin{array}{l}\text { (F) The Study of Equity and Justice of Urban Green Space: } \\
\text { environmental equity and justice in urban social economy are } \\
\text { reflected by measuring accessibility, availability, visiting fluxes } \\
\text { and population exposure }\end{array}$ & 60 \\
\hline 4 & $\begin{array}{l}\text { (G) The Study of Spatial Data and Measurement of Urban Green } \\
\text { Space: geoinformatics measurement and spatial data effects }\end{array}$ & 16 \\
\hline 3 & $\begin{array}{l}\text { (H) The Study of Urban Heat Island: urban thermal environment } \\
\text { and urban heat island related to urban green space }\end{array}$ & 40 \\
\hline 4 & $\begin{array}{l}\text { (I) The Study of Urban Habitat and Biodiversity: relationships } \\
\text { between the anthropogenic activities and urban biodiversity in } \\
\text { the urban habitat are investigated, through the analysis of green } \\
\text { space connectivity, internal species abundance/richness, species } \\
\text { distribution, and plant community }\end{array}$ & 48 \\
\hline- & (J) Other Related Studies & 20 \\
\hline
\end{tabular}




\section{Results}

\subsection{Regional Distribution of Studies}

Literature reviewed for this paper cover 44 countries and regions. They show a certain degree of regional concentration based on the subject categories of the research focus in their respective regions (Table 3). Asia has the greatest number of studies (149), in which China contributed 122, accounting for $40.1 \%$ of the total potential literature. Europe (95) then followed in concentration by the United Kingdom (23), Germany (15), Turkey (10), and Poland (9). North America and Oceania are dominated by the United States (31) and Australia (12). Only a few studies have been carried out in South America and Africa.

Table 3. The frequency of subject categories and the regional distribution of potential literature.

\begin{tabular}{|c|c|c|c|c|c|c|c|c|}
\hline Types & China $^{a}$ & $\begin{array}{c}\text { Asia (Except } \\
\text { China) }\end{array}$ & Europe $^{c}$ & America $^{d}$ & Oceania $^{e}$ & Africa $^{\mathrm{f}}$ & Sum & Percentage \\
\hline $\mathrm{A}$ & 10 & 2 & 4 & 0 & 2 & 0 & 18 & 5.9 \\
\hline B & 23 & 5 & 3 & 1 & 0 & 0 & 32 & 10.5 \\
\hline $\mathrm{C}$ & 5 & 3 & 12 & 3 & 2 & 1 & 26 & 8.5 \\
\hline $\mathrm{D}$ & 4 & 1 & 4 & 5 & 0 & 0 & 14 & 4.6 \\
\hline $\mathrm{E}$ & 14 & 3 & 10 & 3 & 0 & 0 & 30 & 9.9 \\
\hline F & 15 & 5 & 25 & 12 & 3 & 0 & 60 & 19.7 \\
\hline G & 7 & 0 & 5 & 3 & 1 & 0 & 16 & 5.3 \\
\hline $\mathrm{H}$ & 28 & 4 & 5 & 3 & 0 & 0 & 40 & 13.2 \\
\hline I & 7 & 3 & 18 & 12 & 6 & 2 & 48 & 15.8 \\
\hline $\mathrm{J}$ & 9 & 1 & 9 & 0 & 0 & 1 & 20 & 6.6 \\
\hline Sum & 122 & 27 & 95 & 42 & 14 & 4 & 304 & 100.0 \\
\hline Percentage & 40.1 & 8.9 & 31.3 & 13.8 & 4.6 & 1.3 & 100.0 & - \\
\hline
\end{tabular}

a: Chinese mainland (111), Hong Kong (6), Taiwan (5); ${ }^{\text {: }}$ Japan (5), India (5), Singapore (4), Iran (4), South Korea (3), Indonesia (3), Malaysia (2), Qatar (1); c: Britain (23), Germany (15), Turkey (10), Poland (9), France (5), Finland (3), Portugal (3), Sweden (3), Switzerland (3), Spain (3), Italy (3), Denmark (2), Netherlands (2), Croatia (2), Romania (2), Greece (2), Austria (1), Bulgaria (1), Russia (1), Czech Republic (1), Slovakia (1); ${ }^{\mathrm{d}}$ : United States (31), Canada (4), Mexico (3), Chile (2), Argentina (1), Brazil (1); ${ }^{\mathrm{e}}$ : Australia (12), New Zealand (2); ${ }^{\mathrm{f}}$ : Egypt (1), Congo (1), Ghana (1), South Africa (2).

China has contributed more than half of the type (A) articles, which is also one of the priority topics in Poland and Australia. Most of the type (B) articles come from Asian countries with China contributing over $70 \%$. Type (C) articles have received widespread attention, except for in South America, and are evenly distributed. Type (D) and (E) studies are mostly conducted in China, the United States, and western European countries represented by Britain. Being the subject category that receives the most attention in studies on urban green space morphology, type (F) accounts for $19.7 \%$ of the total potential literature, while type $(G)$ covers relatively few articles. The regional distribution of type $(H)$ is similar to that of type (B), both of which are the focus of China's research, and account for over $40 \%$ of China's literature. Type (I) has received worldwide attention, especially in countries such as the United States, China, Australia, Germany, and Britain. Type (J) is mainly conducted by a few countries in Asia, Central Europe, and western Europe. The above reflects the regional research interest in various related subject categories of urban green space morphology.

\subsection{Frequency of Publications}

The earliest study of urban green space morphology confirmed in this review dates back to 1995. In the 15 years thereafter, the number of potential literature had always been low with less than four articles per year. Since 2010, relevant research has gradually increased in a step-wise manner and can be generally divided into three stages: 12 articles per year from 2010 to 2012; nearly averaging 30 articles per year from 2014 to 2016; maintaining about 45 articles per year since 2017 (Table 4). 
Table 4. The frequency of subject categories and years of publication of potential literature.

\begin{tabular}{cccccccccccc}
\hline & A & B & C & D & E & F & G & H & I & J & Sum \\
\hline 2019 & 1 & 3 & 2 & 3 & 3 & 10 & 3 & 9 & 4 & 4 & 42 \\
2018 & 1 & 3 & 3 & 5 & 5 & 15 & 4 & 2 & 4 & 4 & 46 \\
2017 & 1 & 5 & 4 & 1 & 2 & 11 & 3 & 11 & 7 & 3 & 48 \\
2016 & 3 & 2 & 6 & 2 & 5 & 3 & 1 & 2 & 3 & 2 & 29 \\
2015 & 0 & 4 & 3 & 1 & 6 & 6 & 1 & 4 & 6 & 1 & 32 \\
2014 & 2 & 3 & 2 & 0 & 1 & 4 & 1 & 6 & 6 & 2 & 27 \\
2013 & 1 & 2 & 3 & 0 & 0 & 1 & 1 & 2 & 4 & 1 & 15 \\
2012 & 0 & 1 & 1 & 0 & 4 & 1 & 1 & 1 & 2 & 1 & 12 \\
2011 & 1 & 3 & 0 & 0 & 1 & 3 & 0 & 0 & 2 & 0 & 10 \\
2010 & 3 & 1 & 0 & 0 & 1 & 0 & 0 & 2 & 3 & 1 & 11 \\
2009 & 2 & 1 & 0 & 1 & 0 & 1 & 0 & 0 & 1 & 0 & 6 \\
2008 & 0 & 0 & 0 & 0 & 0 & 1 & 0 & 1 & 2 & 0 & 4 \\
2007 & 0 & 1 & 0 & 1 & 0 & 3 & 1 & 0 & 0 & 0 & 6 \\
2006 & 0 & 2 & 1 & 0 & 0 & 1 & 0 & 0 & 0 & 0 & 4 \\
2005 & 1 & 1 & 0 & 0 & 0 & 0 & 0 & 0 & 0 & 1 & 3 \\
2004 & 0 & 0 & 1 & 0 & 1 & 0 & 0 & 0 & 1 & 0 & 3 \\
2003 & 1 & 0 & 0 & 0 & 0 & 0 & 0 & 0 & 1 & 0 & 2 \\
2002 & 0 & 0 & 0 & 0 & 1 & 0 & 0 & 0 & 1 & 0 & 2 \\
2000 & 0 & 0 & 0 & 0 & 0 & 0 & 0 & 0 & 1 & 0 & 1 \\
1995 & 1 & 0 & 0 & 0 & 0 & 0 & 0 & 0 & 0 & 0 & 1 \\
Sum & 18 & 32 & 26 & 14 & 30 & 60 & 16 & 40 & 48 & 20 & 304 \\
\hline
\end{tabular}

Even though type (A) started the earliest, it always received insufficient attention and did not have a steady development. In contrast, type (I), which started relatively early and underwent a brief interruption in 2005, has attracted a certain level of attention and has shown fluctuating growth since 2008. Type (B) and $(F)$ have been growing steadily since about 2006, especially the latter, which has been receiving incremental attention in the last three years. Type (E) and (J) caught the eyes of some scholars in the early 2000s, but they did not make much progress for 5 years thereafter until 2010, when they returned to the perspective of relevant scholars and exhibited a certain growth trend. Continuous focus for type (C), (G) and (H) started from 2012, in which type (H) has become one of the most popular subject categories in recent years. Only in the past 5 years did type (D) again involve the urban green space morphology.

\subsection{Main Source Publications}

The literature reviewed for this paper cover 100 peer-reviewed journals. Table 5 lists the top 10 source journals in terms of the number of contributions, which published nearly $45 \%$ of the total 304 potential literature. Among them, only "Landscape and Urban Planning" and "Urban Forestry \& Urban Greening" cover all subject categories, contributing 76 articles (25\%). "Sustainability" (14) and "Urban Ecosystems" (11) then follow, with emphasis on type (F) and type (I), respectively. The other six main journals, "Ecological Indicators", "Journal of Urban Planning and Development", "Landscape Ecology", "International Journal of Environmental Research and Public Health", "ISPRS International Journal of Geo-Information" and "PLoS One", focus on 3-5 subject categories of urban green space morphology, generally valuing type $(F)$ and type $(H)$, while type $(D)$ and type (E) receive relatively insufficient attention. 
Table 5. Main source publications of potential literature and the frequency of subject categories.

\begin{tabular}{|c|c|c|c|c|c|c|c|c|c|c|c|}
\hline & $\mathbf{A}$ & B & $\mathrm{C}$ & $\mathbf{D}$ & $\mathrm{E}$ & $\mathbf{F}$ & G & $\mathbf{H}$ & I & $\mathbf{J}$ & Sum \\
\hline $\begin{array}{l}\text { Landscape and } \\
\text { Urban Planning }\end{array}$ & 2 & 5 & 3 & 2 & 4 & 9 & 2 & 4 & 13 & 3 & 47 \\
\hline $\begin{array}{l}\text { Urban Forestry \& } \\
\text { Urban Greening }\end{array}$ & 1 & 2 & 4 & 2 & 5 & 3 & 1 & 6 & 4 & 1 & 29 \\
\hline Sustainability & 2 & 0 & 0 & 0 & 1 & 6 & 0 & 3 & 1 & 1 & 14 \\
\hline Urban Ecosystems & 0 & 1 & 2 & 2 & 1 & 0 & 0 & 1 & 4 & 0 & 11 \\
\hline $\begin{array}{l}\text { Ecological Indicators } \\
\text { Journal of Urban }\end{array}$ & 0 & 0 & 1 & 2 & 0 & 1 & 0 & 2 & 0 & 2 & 8 \\
\hline $\begin{array}{l}\text { Planning and } \\
\text { Development }\end{array}$ & 1 & 2 & 1 & 0 & 0 & 1 & 0 & 0 & 1 & 0 & 6 \\
\hline Landscape Ecology & 0 & 0 & 0 & 0 & 0 & 0 & 1 & 2 & 3 & 0 & 6 \\
\hline $\begin{array}{c}\text { International Journal of } \\
\text { Environmental } \\
\text { Research and } \\
\text { Public Health }\end{array}$ & 0 & 1 & 1 & 0 & 0 & 2 & 0 & 1 & 0 & 0 & 5 \\
\hline $\begin{array}{l}\text { ISPRS International } \\
\text { Journal of } \\
\text { Geo-Information }\end{array}$ & 0 & 0 & 0 & 0 & 0 & 2 & 0 & 2 & 0 & 1 & 5 \\
\hline PLoS One & 1 & 0 & 0 & 0 & 0 & 0 & 2 & 0 & 2 & 0 & 5 \\
\hline
\end{tabular}

\subsection{Knowledge Frame and Research Category}

Combined with the analysis of the structure and pattern of scientific knowledge presented by CiteSpace, this article further interprets and sorts out the research category of urban green space morphology.

As shown in Figure 1, among all the clusters formed in CiteSpace, combined with the analysis of potential labels in Table 1, cluster (2) mainly focuses on urban green space (409.43); however, there are two ways in which cluster (2) is viewed and practiced. On the one hand, architecture studies from the perspective of urban green space planning (type A). On the other hand, urban ecology regards it as urban green infrastructure, urban forest, and urban agriculture (387.92) (type D). By associating cluster (2) with cluster (1), it further reflects that urban green space (118.37), being the only spatial entity with natural biological activity and regeneration mechanism in the urban ecosystem, is a critical component for achieving sustainable development in urban areas. The sustainable urban greening strategies (118.45) and management (type C) employed, especially in compact cities (201.21), also involve the environmental equity and justice (type F) in cluster (5) of socio-ecological exploration (108.35), which is reflected in the socio-economic inequalities (140.58), private land (140.58) and differential community effect (134.86). The urban ecosystem service (type E) usually measured by carbon storage (133.14) and urban tree stock (124.50) is also supporting urban sustainable development through its tangible urban green infrastructure. By correlating cluster (2) with cluster (0), it indicates that the urban green space practice mainly relies on the network model (148.60) provided by the study of urban green space pattern (type B) in the field of landscape ecology as the conceptual support. Landscape metrics (152.92) and spatial-temporal gradient analysis (169.28) are normally combined to investigate the urban landscape spatial pattern (311.98) and its impacts on land surface temperature (301.77), urban heat island pattern (158.66) and the anisotropic cooling distance (150.02) (type $\mathrm{H}$ ), which results in the establishment of the correlation between cluster (0) and cluster (3). Meanwhile, cluster (0), which represents the studies on the urban green space pattern and urban landscape pattern, also applies to the urban environment (102.32) science and urban environment element (136.46). Moreover, based on the data and geoinformatics measurement of urban green space (Type G) including aerial photograph (68.76), high spatial resolution data (68.76) and mapping land cover (68.76), technological means are provided for the study of biodiversity conservation (102.32) and relevant urban habitats (Type I) in cluster (4). 


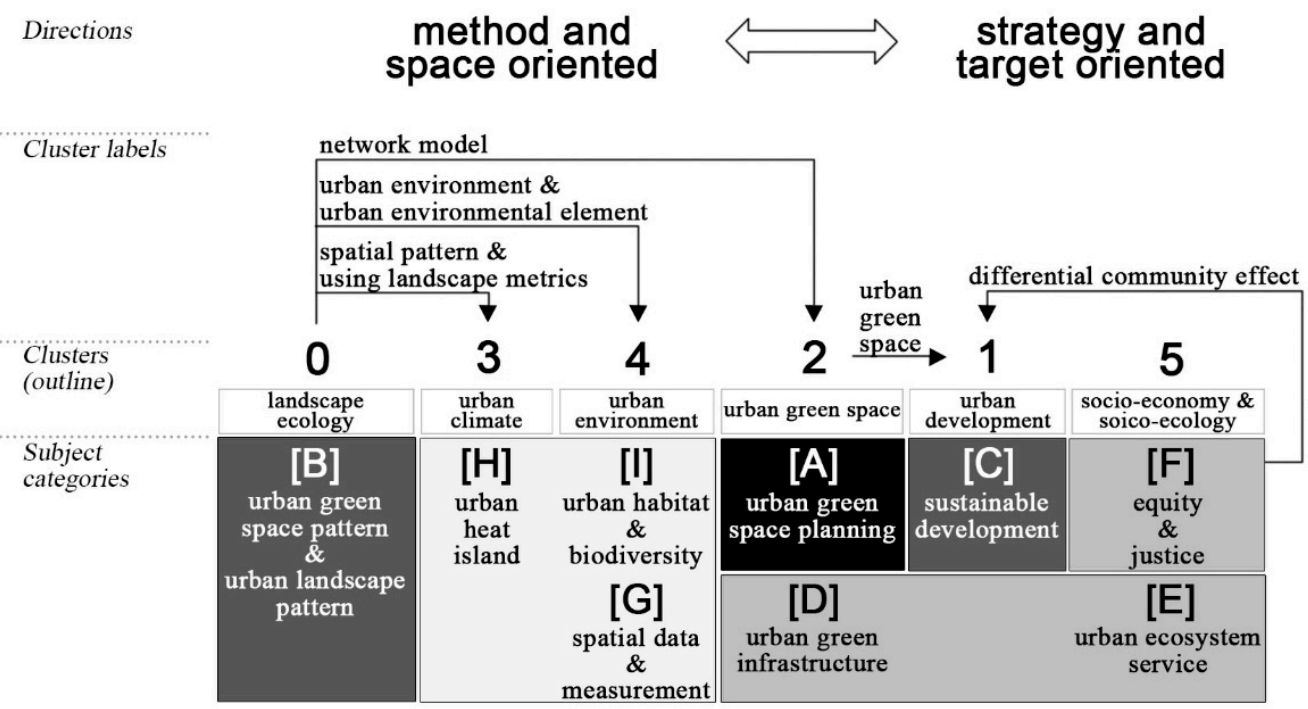

Figure 1. Research category of urban green space morphology and related knowledge frame.

This paper holds that the research category of urban green space morphology mainly covers the type (A) as the carrier of practice; it also covers type (B) and type (C) which are directly related to type (A). Type (B) and type (C) are, respectively, space-oriented method supports and target-oriented development strategies.

\subsection{Research Frontiers}

This part will discuss in detail the research progress, and frontier methods and technologies of each type within the research category. Table 6 presents the general state of the main analytical methods used in relevant studies for reflecting different morphological levels. In terms of research approaches, more than $60 \%$ are case-based empirical studies, while normative studies account for about $30 \%$, and the rest are reviews. Most quantitative analysis methods are applied to the "pattern" level (about 45\%). Both "distribution" and "form-rule" levels of studies account for about $25 \%$, in which the former tends to emphasize the spatial location attribute of urban green space and lacks the quantification of its composition attribute. On the other hand, the latter focuses on the application of qualitative analysis methods. In contrast, studies on the "form-structure" level (about 5\%) and related technical methods are insufficient.

Table 6. Main methods for different morphological levels within the research category.

\begin{tabular}{|c|c|c|c|c|c|c|c|c|c|c|c|c|c|c|}
\hline \multirow{2}{*}{$\begin{array}{l}\text { Morphological } \\
\text { Levels }\end{array}$} & \multicolumn{14}{|c|}{ Methods Used * } \\
\hline & CA & FG & GDA & GIS & GTM & LM & LS & MSA & MSPA & 0 & $\mathbf{R}$ & RS & SI & SS \\
\hline $\mathrm{D}$ & 3 & 0 & 0 & 4 & 0 & 0 & 6 & 4 & 0 & 0 & 2 & 3 & 4 & 0 \\
\hline FS & 0 & 0 & 0 & 2 & 2 & 0 & 0 & 0 & 0 & 0 & 1 & 2 & 0 & 0 \\
\hline FR & 2 & 2 & 0 & 0 & 0 & 0 & 10 & 1 & 0 & 2 & 1 & 0 & 5 & 0 \\
\hline $\mathrm{P}$ & 1 & 0 & 12 & 17 & 3 & 17 & 0 & 8 & 3 & 0 & 1 & 15 & 0 & 1 \\
\hline
\end{tabular}

${ }^{*} \mathrm{D}$-distribution, FS—-form structure, FR-form rule, $\mathrm{P}$ - pattern, CA-comparative analysis, FG—focus groups, GDA-gradient and dynamic analysis, GIS—geographic information system, GTM-graph theoretic modelling, LM-landscape metrics, LS-literature survey, MSA — multivariate statistical analysis, MSPA — morphological spatial pattern analysis, O—observation, R—review, RS—remote sensing, SI-survey and interview, SS—spatial statistics. Numbers indicate the number of studies. Please note that papers may use more than one method.

\subsubsection{Urban Green Space Planning}

The study of urban green space planning aims at practicality and shows the rich development in chronological order. Combined with the explanation of the open space plans and the green strategies for London, Turner emphasized that greenway is an important way to realize the flexibility and differentiation of urban open space; he also summarized 
seven archetypes for urban greenway and their relative elements, problems, and solutions by referring to Alexander's pattern language [4].

Until the early 21st century, Jim and Chen, based on the principles of landscape ecology, constructed the framework of comprehensive urban green space planning in compact cities, which was comprised of first, green wedge adapted to urban form at the metropolitan scale; second, the green network combining terrain, urban development background and conservation elements at the city scale; third, green expansion complying to social and ecological functions at the neighborhood scale [5]. Over the next 15 years, relevant studies actually enriched the framework at different spatial scales. At the neighborhood-city scale, Ishii et al. reviewed the effects of religious and cultural background on the spatial distribution and management of Japanese shrine/temple forests from the sociological perspective. They then discussed the reduction in species richness resulting from forest fragmentation and invasive species under the effect of urbanization from an ecological perspective and emphasized the necessity to establish ecologically scientific and sociopolitical basis of urban landscape planning [6]. As the supply capacity of the formal green space system was increasingly affected by the urbanization process, Rupprecht and Byrne focused on the identification of the different concepts and types of informal urban green space and reviewed them systematically; the socio-ecological function of informal urban green space was highlighted [7]. At the city scale, Yin et al. developed an urban green space network and analyzed its ecological sensitivity of urban land use by the least cost patch function; they also completed the scenario design for the landscape ecological security development; finally, they revealed the trends in urban growth and the effects on landscape ecological security for different scenarios using an existing cellular automaton model [8]. At the metropolitan scale, Rosada et al. identified the compositions of historical park and garden complexes existing in the wedge-ring system of urban green space and investigated their current conditions and functions to the urban green space system [9].

In recent years, some scholars have focused on building a more comprehensive urban green space planning framework. Based on the lexical correspondence analysis and network text analysis on the abstracts of scientific papers with "green" and "green network" as the main topics, Tulisi illustrated the transformation of green space's role in urban planning over the last 20 years. He provided a unique definition of "urban green network design" to support urban planning practice more precisely, due to the fuzzy and unclear interpretation of the concept of green network [10]. Badach and Raszeja selected and compared the ecological, visual and structural landscape and greenspace indicators (LGIs) relevant for urban areas; they then developed a conceptual framework for the implementation of LGIs and tentatively indicated the applicability of the selected LGIs in the landscape and greenspace management provisions at various levels of urban spatial planning system, with the purpose of guiding the sustainable landscape transformation in the future [11].

Therefore, the constant improvement in the systematic cognition of urban green space planning is reflected in the multi-dimensional and multi-scale exploration of urban green space network construction referring to the principles of landscape ecology.

\subsubsection{Urban Green Space Pattern and Urban Landscape Pattern}

In general, the study of urban green space pattern is based on the model of "patchcorridor-matrix" in landscape ecology and emphasizes the unique structure resulting from the spatial arrangement of urban green patches and corridors. However, the difference in the cognition of urban green space may lead to different analytical methods, which fall into three categories. The first one is to view urban green space as one of the urban land use types. Based on the landscape metrics of different levels and combined with the sampling methods of moving window and belt transect, the characteristics and spatiotemporal dynamics of the overall pattern of urban land use types including urban green space were analyzed [12-14]. Some studies adjusted the size of the moving window appropriately for urban green space with specific uses $[15,16]$. The second category focuses 
on urban ecological network, which is primarily based on graph theory. By employing landscape-metrics-based calculations and comparing the current and prospective green space distribution in urban greenspace/greenway system planning, together with network analysis, the practice of urban ecological network planning was guided [17,18]. For specific green space uses, based on the evolution in the spatiotemporal dynamics of urban land uses and the distribution of green space types, Serret et al. quantified the potential contribution of specific green space type to regional connectivity using least cost path geometry to evaluate the strategic position of green space at business sites in the urban ecological network [19]. The third category incorporates the morphological spatial pattern analysis (MSPA) with landscape ecological principles to describe the urban green infrastructure pattern [20]. According to the MSPA spatial pattern classes, the functional niches of landscape were defined as existing core areas, existing/potential connectors including islets. A future urban green infrastructure scenario with hierarchical hubs, links, and sites can be delineated. Finally, by contrasting between the plan scenario and the basic ecological control line, some focus areas for management strategies can be identified [21,22].

The study of urban landscape pattern is based on the "land mosaics" spatial model and it highlights the patchiness of urban land cover. Based on medium resolution satellite remote sensing data, multiple endmember spectral mixture analysis was applied to derive green space coverage at the sub-pixel level, or the green space changes and land cover types were identified with the normalized difference vegetation index (NDVI). Finally, landscape metrics were used to analyze the spatiotemporal characteristics of the landscape pattern $[23,24]$. Similarly, urban land index, urban expansion (intensity) index and other explanatory variables that were used to describe the level of urbanization can demonstrate that the rapid urbanization directly resulted in more fragmented green space patches, in particular the occupation of green space by high density built-up areas and intensive urban expansion mainly at the cost of agricultural land in the urban fringe [25-27]. Given that the high resolution satellite remote sensing data can accurately measure the urban green space cover, they were used to investigate the accumulated frequency distribution of patches in terms of patch size and especially to quantify the aggregation and fragmentation of urban green space at the patch level [28-30].

Landscape metrics constitute one of the most important analytical methodologies in the study of urban green space pattern and urban landscape pattern. Although there are numerous landscape metrics, they are often not statistically independent of each other in the selection. In this regard, after correlating the sustainability topics, research issues and landscape metrics in the relevant literature, Luo pointed out that the selection of landscape metrics should consider the spatial pattern interpretation from the perspective of green space environmental functions to better support the measurement of sustainable development of urban green space [31]. Some scholars harness statistical science to conduct quantitative studies of landscape metrics. Tian et al. characterized the landscape mosaics by different districts with some key indices concerning patch size, patch shape, proximity relationship, and edge configuration. All selected landscape metrics were standardized based on the standard deviation model and converted into a set of values of linearly uncorrelated variables called principal components to comprehensively quantify the ecological quality of urban green space. Assisted by the eigenvalues of the principal components and the loading values of the corresponding metrics, the fragmentation index can be formulated to assess fragmentation levels of urban green space by sample units [32,33]. Liang et al. reduced the data dimension of the landscape metrics at the landscape level through correlation analysis and factor analysis, then calculated the integrated scores of each landscape metric class by districts based on the weight of variance contribution ratio of each common factor, and quantified the characteristics of urban green space pattern in different districts combined with the hierarchical cluster analysis [34]. The above-mentioned studies provide beneficial thoughts for improving the scientific selection of landscape metrics.

Based on the level of pattern, landscape ecology has contributed a fundamental technical basis for the relevant studies of urban green space morphology. Furthermore, 
it also constantly tests effective ways to conceptualize urban green space in order to be appropriately applied to practice.

\subsubsection{Strategies, Planning Management and Solutions for Sustainable Development of Urban Green Space}

With regard to this study category, there is a game between two ways of thinking. On the one hand, it tends to coordinate the request of various stakeholders for environmental equity and justness from the bottom up. Facing the paradoxical effects such as gentrification under the urban green space intervention implemented by the local government, Wolch et al. called on urban planners, designers, and ecologists to focus on bottom-up urban green space strategies that are "just green enough" in order to protect social, as well as ecological, sustainability [35]. Sondermann emphasized the cooperation of planning practice between civil society and political-administrative actors to explore the specific forms of negotiating spatial development on the local level [36]. This argument is reflected by some of the cases of the nature-based solutions of the Resilient European project, in which practices presented the specific requirements for multiple disciplines for design, diversity for co-creation, and the importance of recognizing the place-based transformative potential [37]. Related quantitative research is mainly based on the identification of the stakeholder-led socio-ecological innovation sites in urban green space management. The spatial distribution and site types were found to be significantly associated with local environmental conditions of land cover and socio-economic characteristics. It was evidenced that the decentralized approach to urban natural resource management is an important adaptive and diverse response contributing to the resilience in socio-ecological system [38,39]. Similarly, McClintock et al. determined the extent of residential urban agriculture and its potential contribution to urban food system resilience occurring in a spatially and socioeconomically uneven manner; they also determined whether the motivations of gardeners differ along these same socio-spatial lines. The results demonstrated that more educated respondents engage for environmental reasons, and more low-income respondents rely on their gardens for food security, which emphasizes that the policymaking of urban sustainable development is sensitive to various motivations that resonate with a diverse population [40].

On the other hand, due to the downward pressure created by limited land resources for the compact city, and the lower per capita green coverage and park provision ratio resulting from the increasing population density, it emphasized the top-down organization of urban green space provision to maintain a high level of urban greening [41]. Boulton et al. made a systematic quantitative review of the greenspace provision literature and offered a conceptual model. This study analyzed the research methods, research scales, greenspace supply and demand, and approaches to describing, measuring and planning in the greenspace provision literature; it also emphasized the interactions between eight green space provision factors including resources, governance tools, political leadership, opportunity for land, governance structure, economies and markets, and organizational culture. It facilitated the formation of effective policies and strategies to satisfy sustainability objectives and to narrow the gap between planned and actual greenspace provision [42]. In terms of the quantitative model study, Stott et al. evaluated the specific form of the functional relationship between urban development intensity and ecosystem service provision and compared the green space provision under the urban development modes of land sharing and land sparing. By combining the case studies of ecosystem service provision along urbanization gradients, they demonstrated that land sparing is crucial for sustaining a majority of ecosystem services. Through illustrating the continuum of sharing to sparing, they determined top-down, policy-led approaches to urban development can ensure that the distribution of green space is optimal for ecosystem service provision [43]. According to a natural procession in the planning-management stream of urban greening in practice study, Jim conducted a literature review on sustainable urban greening strategies for compact cities based on three main stages of applying urban ecological principles, protecting natural assets of cities, and augmenting greening opportunities [44]. Later, he traced 25 concerns with reference to three themes: open-space planning standards, 
urban-design guidelines, and urban-greening governance, and explored the root cause of urban green space deficiency due to institutional and spatial limitations. By comparing the urban green space standards of the selected cities and related research findings and practices, they offered recommendations and solutions to green space provision for the compact city [45].

However, incomplete knowledge of ecosystem dynamics and institutional constraints in many conventional natural resource management regimes often leads to institutional management framework that does not match the scale of the ecological pattern and process. Thus, promoting the improvement of cross-scale, multi-role, and multi-dimensional urban green space management and planning strategies is necessary. Borgström et al. synthesized two frameworks: management of ecological scales and hierarchical planning with the ecosystem management criteria. Based on these frameworks, a qualitative study of current urban green space management practices was conducted. It was emphasized that one potential effect of neglecting the ecological cross-scale interactions in the highly fragmented urban landscape is a gradual reduction in the capacity of the ecosystem to provide ecosystem services [46]. Some studies embedded social networks into urban green space management across the spatiotemporal scales and investigated the channels that knowledge is transferred between public administrators and policymakers, practitioners, and academicians. Combining environmental education, the different modes of collaboration and interaction in practice by stakeholders were explored. At the level of physical space, the integration of informal green space can first improve the state that existing green space planning standards are unable to meet the local's social and ecological needs, then it can strengthen the urban socio-ecological resilience [47-49]. The multi-dimensional development of related studies has been reflected in the construction of the theoretical framework of urban green space management and planning policy in terms of economic, social, and ecological dimensions [50], and the formulation of strategies and specific improvement measures of urban green space development combined with the three-dimensional green network [51].

In the recent years, numerous novel ideas such as urban green infrastructure, naturebased solutions, biophilic urbanism, IUCN (International Union For Conservation Of Nature) Best Practices Guidelines, UNESCO (United Nations Educational Scientific And Cultural Organization) Man and Biosphere Programme, edible city, forest city, healing garden and informal green space emerged; alongside the increased accessibility of opensourced data and information of urban green space, scholars have begun to contemplate the applicability and necessity of those ideas in the urban green space planning and management [52,53].

\section{Discussion}

Given the above analysis, this paper suggests that there are several problems in the relevant research on urban green space morphology. In fact, the efforts of some scholars have partially made up for these deficiencies, consciously combining respective morphological understandings of urban green space.

First, the studies on urban green space planning explore the construction of urban green space networks primarily based on principles of landscape ecology. However, such methods often weaken the complexity of the urban environment influenced by human activities compared to the natural base.

In this regard, it is necessary to stress the explicit spatial relationship between urban green space and urban form, as some scholars made attempts at different scales. For the city scale, Huang et al. evaluated the impact of urban form on landscape structure of urban green space using boosted regression tree analysis with the urban form and landscape metrics [54]. By analyzing the correlations between metropolitan boundary, natural boundary, and urban boundary and their influence on the level of green space, Wang et al. emphasized the ecological value of large-scale natural resources within or surrounding the metropolis [55]. With regard to the district scale, Chang and Chen explored the 
spatial heterogeneity of relationships between urban green space allocation and urban compaction level in each basic unit of township using the geographically weighted regression model $[56,57]$. At the neighborhood scale, by taking advantage of high resolution satellite remote sensing data, Gupta et al. and Liu et al. established the building-oriented urban neighborhood green index model to analyze the distribution of urban green space in the vicinity of urban built-up, so as to enhance the sensitivity to the identification of spatial distribution characteristics of urban green space [58,59].

Second, the results of the above studies on urban green space pattern and urban landscape pattern have proven to be somewhat insufficient when called upon to address the pressing questions from practitioners. The studies tend to focus more on quantitative analysis instead of analyzing the mechanisms. The quantitative analysis of the pattern is the key to study the dynamic and function of urban landscape. By integrating with the eco-environmental efficiency and urban planning, the pattern can ultimately affect the urban ecosystem services.

For example, the visually assigned green space classes can be connected by the proportion of their tree canopy and ecosystem services [60]. A matrix of urban vegetation structure types can be constructed based on an urban biotope map and information from terrestrial datasets and aerial images, combined with using the proportion of green area, specific green volume and proportion of sealed area as parameters, to undertake the assessment of the ecological conditions for concrete sites [61]. By taking into account the guidance of urban green space planning and design practice, an optimization model based on integer programming can be developed to define the spatial form of urban green space to maximize the potential of delivering different types of ecosystem services [62]. Hayek et al., Neuenschwander et al. mapped the urban green space types, then linked with information on potentially provided ecosystem services and their parameters, and finally integrated with typical green space pattern designs described with a form-based code into the procedural modeling, resulting in 3D visualizations of the green space patterns and their related ecosystem service indicators [63,64].

Third, many cities are exploring more comprehensive urban green space management and planning strategies in the context of urbanization. However, investigations on the characteristics of local development from the spatiotemporal dimension are often ignored.

Therefore, apart from considering the urban green space configuration based on land use and land cover and explaining and comparing the urban ecological conditions using the proportion of green space and relevant land cover area in the structural units [65], the studies should contribute more attention to the spatiotemporal dimension. To be specific, urban green space can be examined from the high-resolution satellite remote sensing data to decide the distribution of green space in places with different construction completion dates, types of land use, and types of residential land [66]. Using the data of moderate resolution imaging spectroradiometer, the localized spatial association analysis under temporal context should be proposed to explore the significant urban greenness changes in the directional transects and concentric belts and their correlation with the land cover changes [67]. Based on sample data, Pauleit et al., for instance, made a grid analysis using aerial photographs taken in different time periods to explore the characteristics, changes and environmental consequences of land use and land cover of the residential area samples; the authors further revealed the loss of green space by relating to the socio-economic status of the areas [68]. Sikuzani et al. used a stratified random sampling of green space from the main roads and compared the differences in the parameters of green space types, vegetation characteristics, green space management and life forms between urban and peri-urban zones [69].

The historico-geographical approach in the urban morphology research can facilitate the integration of social economy and material culture. Inspired by Conzen School, the historical land-use development of urban fringe belts can be examined based on detailed research on fluctuations in urban development patterns [70]. Combined with the findings of urban morphological research on green space in both the continuous fringe belts pre- 
dominantly associated with physical "fixation lines" and discontinuous fringe belts based on land use, Whitehand underlined the necessity of integrating historico-geographical thinking into the research and practice of urban green space. He further emphasized the significance of fringe belts as they provide a frame of reference, within which the phases of development and physical manifestations of previous historical periods can be related to the environments of present urban areas [71].

\section{Conclusions}

We can draw the following conclusions based on the study mentioned above. First, compared with other countries and regions, China has demonstrated a larger amount of research in the contributions to the study of urban green space morphology. Over the past 10 years, as urban green space morphology has received increasing attention from relevant scholars, its knowledge frame has presented generally two directions: strategy and target oriented, and method and space oriented. Second, the research category of urban green space morphology mainly covers the study of urban green space planning, the study of urban green space pattern and urban landscape pattern, and the strategies, planning management, and solutions for sustainable development of urban green space. Third, the research ideas and methods within the research category of urban green space morphology are relatively scattered, which requires a concerted framework that integrates theoretical cognition and operational methods and technologies.

This paper endeavors to establish the comprehensive evidence base to support research on urban green space morphology, which term is proposed as an important way to perform urban resilience and sustainability integrated the landscape ecology and landscape architecture. In the future, the study of urban green space morphology at the city scale requires comprehensive applications of the research results of contemporary urban morphology and urban landscape ecology, as well as the practice of urban planning, urban design and landscape architecture, and also needs in-depth integration of different research directions and methods in an overall theoretical framework so as to achieve the goal of an optimal spatial layout and pattern of urban green space.

Supplementary Materials: The following is available online at https:/ / www.mdpi.com/2071-1050/ 13/3/1202/s1, Table S1: A complete list of potential literature.

Author Contributions: Conceptualization, X.W. and H.Z.; methodology, H.Z. and X.W.; software, H.Z.; investigation, H.Z.; data curation, H.Z.; writing-original draft preparation, H.Z.; writingreview and editing, H.Z. and X.W.; visualization, H.Z.; supervision, X.W. All authors have read and agreed to the published version of the manuscript.

Funding: This research was funded by the National Natural Science Foundation of China, grant number 50978054 and 51878144 and Postgraduate Research and Practice Innovation Program of Jiangsu Province, grant number KYCX17_0163.

Institutional Review Board Statement: Not applicable.

Informed Consent Statement: Not applicable.

Data Availability Statement: The data presented in this study are available on request from the corresponding author.

Conflicts of Interest: The authors declare no conflict of interest.

\section{References}

1. Swanwick, C.; Dunnett, N.; Woolley, H. Nature, role and value of green space in towns and cities: An overview. Built Environ. 2003, 29, 94-106. [CrossRef]

2. Chen, C.; Song, M. Visualizing a field of research: A methodology of systematic scientometric reviews. PLoS ONE 2019, 14, e0223994. [CrossRef]

3. How to Use Cite Space. Available online: https:/ /leanpub.com/howtousecitespace (accessed on 18 January 2021).

4. Turner, T. Greenways, blueways, skyways and other ways to a better London. Landsc. Urban Plan. 1995, 33, 269-282. [CrossRef] 
5. Jim, C.; Chen, S.S. Comprehensive greenspace planning based on landscape ecology principles in compact Nanjing city, China. Landsc. Urban Plan. 2003, 65, 95-116. [CrossRef]

6. Ishii, H.R.; Manabe, T.; Ito, K.; Fujita, N.; Imanishi, A.; Hashimoto, D.; Iwasaki, A. Integrating ecological and cultural values toward conservation and utilization of shrine/temple forests as urban green space in Japanese cities. Landsc. Ecol. Eng. 2010, 6, 307-315. [CrossRef]

7. Rupprecht, C.D.D.; Byrne, J. Informal urban greenspace: A typology and trilingual systematic review of its role for urban residents and trends in the literature. Urban For. Urban Green. 2014, 13, 597-611. [CrossRef]

8. Yin, H.; Kong, F.; Hu, Y.; James, P.; Xu, F.; Yu, L. Assessing growth scenarios for their landscape ecological security impact using the SLEUTH urban growth model. J. Urban Plan. Dev. 2016, 142, 05015006. [CrossRef]

9. Rosada, A.; Walerzak, M.; Urbański, P. Historical city parks in the wedge-ring system of urban green space in Poznań. Teka Kom. Urban. Archit. 2016, 44, 299-317.

10. Tulisi, A. Urban green network design defining green network from an urban planning perspective. TeMA J. Land Use Mobil. Environ. 2017, 10, 179-192.

11. Badach, J.; Raszeja, E. Developing a framework for the implementation of landscape and greenspace indicators in sustainable urban planning. Waterfront landscape management: Case studies in Gdańsk, Poznań and Bristol. Sustainability 2019, 11, 2291. [CrossRef]

12. Kong, F.; Nakagoshi, N. Spatial-temporal gradient analysis of urban green spaces in Jinan, China. Landsc. Urban Plan. 2006, 78, 147-164. [CrossRef]

13. Kong, F.; Nakagoshi, N.; Yin, H.; Kikuchi, A. Spatial gradient analysis of urban green spaces combined with landscape metrics in Jinan city of China. Chin. Geogr. Sci. 2005, 15, 254-261. [CrossRef]

14. Zhou, X.; Wang, Y.-C. Spatial-temporal dynamics of urban green space in response to rapid urbanization and greening policies. Landsc. Urban Plan. 2011, 100, 268-277. [CrossRef]

15. Wang, Z.B.; Zhang, L.J.; Zhao, X.L.; Du, H.Y.; Yang, D.Y.; Cai, Y.L. Analysis on landscape pattern of urban green space in Shanghai. J. Environ. Prot. Ecol. 2017, 18, 788-801.

16. Zhang, L.; Wang, Z.; Da, L. Spatial characteristics of urban green space: A case study of Shanghai, China. Appl. Ecol. Environ. Res. 2019, 17, 1799-1815. [CrossRef]

17. Li, H.; Chen, W.; He, W. Planning of green space ecological network in urban areas: An example of Nanchang, China. Int. J. Environ. Res. Public Health 2015, 12, 12889-12904. [CrossRef]

18. Zhang, L.; Wang, H. Planning an ecological network of Xiamen Island (China) using landscape metrics and network analysis. Landsc. Urban Plan. 2006, 78, 449-456. [CrossRef]

19. Serret, H.; Raymond, R.; Foltête, J.-C.; Clergeau, P.; Simon, L.; Machon, N. Potential contributions of green spaces at business sites to the ecological network in an urban agglomeration: The case of the Ile-de-France region, France. Landsc. Urban Plan. 2014, 131, 27-35. [CrossRef]

20. Gonzalez, O.M.R. The green areas of San Juan, Puerto Rico. Ecol. Soc. 2014, 19, 21. [CrossRef]

21. Chang, Q.; Liu, X.; Wu, J.; He, P. MSPA-based urban green infrastructure planning and management approach for urban sustainability: Case study of Longgang in China. J. Urban Plan. Dev. 2015, 141. [CrossRef]

22. Chang, Q.; Qiu, Y.; Li, X.; Wu, J.S. A MSPA-based approach of urban green space system planning. Adv. Mater. Res. 2012, 518, 5972-5979. [CrossRef]

23. Rafiee, R.; Mahiny, A.S.; Khorasani, N. Assessment of changes in urban green spaces of Mashad city using satellite data. Int. J. Appl. Earth Obs. Geoinf. 2009, 11, 431-438. [CrossRef]

24. Yu, Z.; Wang, Y.; Deng, J.; Shen, Z.; Wang, K.; Zhu, J.; Gan, M. Dynamics of hierarchical urban green space patches and implications for management policy. Sensors 2017, 17, 1304. [CrossRef]

25. Chan, K.M.; Vu, T.T. A landscape ecological perspective of the impacts of urbanization on urban green spaces in the Klang Valley. Appl. Geogr. 2017, 85, 89-100. [CrossRef]

26. Jiao, L.; Xu, G.; Xiao, F.; Liu, Y.; Zhang, B. Analyzing the impacts of urban expansion on green fragmentation using constraint gradient analysis. Prof. Geogr. 2017, 69, 553-566. [CrossRef]

27. Li, F.; Zheng, W.; Wang, Y.; Liang, J.; Xie, S.; Guo, S.; Li, X.; Yu, C. Urban green space fragmentation and urbanization: A spatiotemporal perspective. Forests 2019, 10, 333. [CrossRef]

28. Qian, Y.; Zhou, W.; Li, W.; Han, L. Understanding the dynamic of greenspace in the urbanized area of Beijing based on high resolution satellite images. Urban For. Urban Green. 2015, 14, 39-47. [CrossRef]

29. Wang, J.; Zhou, W.; Qian, Y.; Li, W.; Han, L. Quantifying and characterizing the dynamics of urban greenspace at the patch level: A new approach using object-based image analysis. Remote Sens. Environ. 2018, 204, 94-108. [CrossRef]

30. Zhou, W.; Wang, J.; Qian, Y.; Pickett, S.T.A.; Li, W.; Han, L. The rapid but "invisible" changes in urban greenspace: A comparative study of nine Chinese cities. Sci. Total Environ. 2018, 627, 1572-1584. [CrossRef]

31. Luo, T. A review study of landscape metrics support to sustainable development of urban green spaces. In Proceedings of the 47th International Federation of Landscape Architects (IFLA) World Congress, Suzhou, China, 28-30 May 2010; Meng, Z.Z., Chen, X., Eds.; London Science Publishing Ltd.: London, UK, 2010; pp. 414-417.

32. Tian, Y.; Jim, C.; Tao, Y.; Shi, T. Landscape ecological assessment of green space fragmentation in Hong Kong. Urban For. Urban Green. 2011, 10, 79-86. [CrossRef] 
33. Tian, Y.; Jim, C.; Wang, H. Assessing the landscape and ecological quality of urban green spaces in a compact city. Landsc. Urban Plan. 2014, 121, 97-108. [CrossRef]

34. Liang, H.; Chen, D.; Zhang, Q. Assessing urban green space distribution in a compact megacity by landscape metrics. J. Environ. Eng. Landsc. Manag. 2017, 25, 64-74. [CrossRef]

35. Wolch, J.R.; Byrne, J.; Newell, J.P. Urban green space, public health, and environmental justice: The challenge of making cities 'just green enough'. Landsc. Urban Plan. 2014, 125, 234-244. [CrossRef]

36. Sondermann, M. Planning culture as a system of meaning: A study using the example of cooperative green urban development in Düsseldorf, Germany. Spat. Res. Plan. 2017, 75, 45-56.

37. Frantzeskaki, N. Seven lessons for planning nature-based solutions in cities. Environ. Sci. Policy 2019, 93, 101-111. [CrossRef]

38. Dennis, M.; Armitage, R.P.; James, P. Appraisal of social-ecological innovation as an adaptive response by stakeholders to local conditions: Mapping stakeholder involvement in horticulture orientated green space management. Urban For. Urban Green. 2016, 18, 86-94. [CrossRef]

39. Dennis, M.; Armitage, R.P.; James, P. Social-ecological innovation: Adaptive responses to urban environmental conditions. Urban Ecosyst. 2016, 19, 1063-1082. [CrossRef]

40. McClintock, N.; Mahmoudi, D.; Simpson, M.; Santos, J.P. Socio-spatial differentiation in the Sustainable City: A mixed-methods assessment of residential gardens in metropolitan Portland, Oregon, USA. Landsc. Urban Plan. 2016, 148, 1-16. [CrossRef]

41. Tan, P.Y.; Wang, J.; Sia, A. Perspectives on five decades of the urban greening of Singapore. Cities 2013, 32, 24-32. [CrossRef]

42. Boulton, C.; Dedekorkut-Howes, A.; Byrne, J. Factors shaping urban greenspace provision: A systematic review of the literature. Landsc. Urban Plan. 2018, 178, 82-101. [CrossRef]

43. Stott, I.; Soga, M.; Inger, R.; Gaston, K.J. Land sparing is crucial for urban ecosystem services. Front. Ecol. Environ. 2015, 13, 387-393. [CrossRef]

44. Jim, C.Y. Sustainable urban greening strategies for compact cities in developing and developed economies. Urban Ecosyst. 2013, 16, 741-761. [CrossRef]

45. Jim, C.; Chan, M.W. Urban greenspace delivery in Hong Kong: Spatial-institutional limitations and solutions. Urban For. Urban Green. 2016, 18, 65-85. [CrossRef]

46. Borgström, S.T.; Elmqvist, T.; Angelstam, P.; Alfsen-Norodom, C. Scale mismatches in management of urban landscapes. Ecol. Soc. 2006, 11, 16. [CrossRef]

47. Elmqvist, T.; Colding, J.; Barthel, S.; Borgström, S.; Duit, A.; Lundberg, J.; Andersson, E.; Ahrné, K.; Ernstson, H.; Folke, C.; et al. The dynamics of social-ecological systems in urban landscapes-Stockholm and the national urban park, Sweden. Ann. N. Y. Acad. Sci. 2014, 1023, 308-322. [CrossRef] [PubMed]

48. Middle, I.; Dzidic, P.; Buckley, A.; Bennett, D.; Tye, M.; Jones, R. Integrating community gardens into public parks: An innovative approach for providing ecosystem services in urban areas. Urban For. Urban Green. 2014, 13, 638-645. [CrossRef]

49. Ugolini, F.; Massetti, L.; Sanesi, G.; Pearlmutter, D. Knowledge transfer between stakeholders in the field of urban forestry and green infrastructure: Results of a European survey. Land Use Policy 2015, 49, 365-381. [CrossRef]

50. Artmann, M.; Inostroza, L.; Fan, P. Urban sprawl, compact urban development and green cities. How much do we know, how much do we agree? Ecol. Indic. 2019, 96, 3-9. [CrossRef]

51. Tian, Y.; Jim, C.; Tao, Y. Challenges and strategies for greening the compact city of Hong Kong. J. Urban Plan. Dev. 2012, 138, 101-109. [CrossRef]

52. Feltynowski, M.; Kronenberg, J.; Bergier, T.; Kabisch, N.; Łaszkiewicz, E.; Strohbach, M.W. Challenges of urban green space management in the face of using inadequate data. Urban For. Urban Green. 2018, 31, 56-66. [CrossRef]

53. Russo, A.; Cirella, G.T. Modern compact cities: How much greenery do we need? Int. J. Environ. Res. Public Health 2018, 15, 2180. [CrossRef] [PubMed]

54. Huang, C.; Yang, J.; Jiang, P. Assessing Impacts of urban form on landscape structure of urban green spaces in China using Landsat images based on google earth engine. Remote Sens. 2018, 10, 1569. [CrossRef]

55. Wang, H.; Qin, J.; Hu, Y. Influence of three types of boundary on the level of greenspace in cities. Procedia Eng. 2017, 198, 482-489. [CrossRef]

56. Chang, H.-S.; Chen, T.-L. Decision making on allocating urban green spaces based upon spatially-varying relationships between urban green spaces and urban compaction degree. Sustainability 2015, 7, 13399-13415. [CrossRef]

57. Chang, H.-S.; Chen, T.-L. Explore energy consumption feature of urban spatial pattern and open green space. DEStech Trans. Environ. Energy Earth Sci. 2017. [CrossRef]

58. Gupta, K.; Kumar, P.; Pathan, S.; Sharma, K. Urban Neighborhood Green Index-A measure of green spaces in urban areas. Landsc. Urban Plan. 2012, 105, 325-335. [CrossRef]

59. Liu, Y.; Meng, Q.; Zhang, J.; Zhang, L.; Jancso, T.; Vatseva, R. An effective Building Neighborhood Green Index model for measuring urban green space. Int. J. Digit. Earth 2016, 9, 387-409. [CrossRef]

60. Kopecká, M.; Szatmári, D.; Rosina, K. Analysis of urban green spaces based on Sentinel-2A: Case studies from Slovakia. Land 2017, 6, 25. [CrossRef]

61. Lehmann, I.; Mathey, J.; Rößler, S.; Bräuer, A.; Goldberg, V. Urban vegetation structure types as a methodological approach for identifying ecosystem services-Application to the analysis of micro-climatic effects. Ecol. Indic. 2014, 42, 58-72. [CrossRef] 
62. Pribadi, D.O.; Xu, C. Optimizing ecosystem services of urban green spaces based on integer programming approach. In Proceedings of the 2017 International Conference on Smart Cities, Automation \& Intelligent Computing Systems (ICON-SONICS), Yogyakarta, Indonesia, 8-10 November 2017; IEEE: Piscataway, NJ, USA, 2017; pp. 70-75.

63. Hayek, U.W.; Neuenschwander, N.; Halatsch, J.; Regamey, A.R. Procedural modeling of urban green space pattern designs taking into account ecological parameters. In ECAADE 2010: Future Cities, Proceedings of the 28th Conference on Education in Computer Aided Architectural Design in Europe, Zurich, Switzerland, 15-18 September 2010; Schmitt, G., Hovestad, L., VanGool, L., Bosche, F., Burkhard, R., Coleman, S., Halatsch, J., Hansmeyer, M., Konsorski Lang, S., Kunze, A., et al., Eds.; ECAADE-Education \& Research Computer Aided Architectural Design Europe: Brussels, Belgium, 2010; pp. 339-347.

64. Neuenschwander, N.; Hayek, U.W.; Regamey, A.G. Integrating an urban green space typology into procedural 3D visualization for collaborative planning. Comput. Environ. Urban Syst. 2014, 48, 99-110. [CrossRef]

65. Wang, H.F.; Qiu, J.X.; Breuste, J.; Friedman, C.R.; Zhou, W.Q.; Wang, X.K. Variations of urban greenness across urban structural units in Beijing, China. Urban For. Urban Green. 2013, 12, 554-561. [CrossRef]

66. Sun, C.; Tao, L.; Zhao, Q.; Li, X.; Ye, H.; Zhang, G.; Liu, X.; Zhao, Y. Spatial pattern of urban green spaces in a long-term compact urbanization process-A case study in China. Ecol. Indic. 2019, 96, 111-119. [CrossRef]

67. Sha, Z.; Ali, Y.; Wang, Y.; Chen, J.; Tan, X.; Li, R. Mapping the changes in urban greenness based on localized spatial association analysis under temporal context using MODIS Data. ISPRS Int. J. Geo-Inf. 2018, 7, 407. [CrossRef]

68. Pauleit, S.; Ennos, R.; Golding, Y. Modeling the environmental impacts of urban land use and land cover change-A study in Merseyside, UK. Landsc. Urban Plan. 2005, 71, 295-310. [CrossRef]

69. Sikuzani, Y.U.; Kouagou, R.S.; Maréchal, J.; Ilunga, E.I.W.; Malaisse, F.; Bogaert, J.; Kankumbi, F.M. Changes in the spatial pattern and ecological functionalities of green spaces in Lubumbashi (the Democratic Republic of Congo) in relation with the degree of urbanization. Trop. Conserv. Sci. 2018, 11, 1-17. [CrossRef]

70. Zhang, Y. A spatio-temporal study of fringe belts and urban green spaces in Birmingham, UK. Urban Morphol. 2019, 23, 18-26.

71. Whitehand, J.W.R. Green space in urban morphology: A historico-geographical approach. Urban Morphol. 2019, $23,5-17$. 